\title{
Student Attitudes Toward Social Distancing During the Covid- 19 Pandemic in Senior High School
}

\author{
Wahyu Fitriani ${ }^{1}$, Sukardi ${ }^{2 *}$, Hairil Wadi ${ }^{3}$ \\ ${ }^{1,3}$ Sociology Education, The Faculty of Teacher Training and Education, University of Mataram, Mataram, \\ Indonesia \\ ${ }^{2}$ The Faculty of Teacher Training and Education \& Postgraduate, University of Mataram, Mataram, \\ Indonesia \\ *Corresponding Author: Sukardi, The Faculty of Teacher Training and Education \& Postgraduate, \\ University of Mataram, Mataram, Indonesia.
}

\begin{abstract}
This This study aims to determine students' attitudes as well as the differences in students' attitudes towards Covid-19's healthprotocol social distancing in Senior High Schools. This research uses quantitative approach with survey. The population in this study were all senior high school students in East Lombok Regency. The sample for this study was obtained using the Slovin formula, from which a sample size of 389 students' attitudes towards social distancing was obtained. The sample was obtained using a questionnaire which met the research requirement with the help of Google Form. The data were analyzed quantitatively using comparative analysis, namely non-parametric statistics, since the requirements of the analysis was not met. The results showed that students 'attitudes towards social distancing tended to be positive. This can be seen from cognitive aspects, which were categorized as high (93.60\%), the affective aspects which were categorized as fair (63.80\%) and connotative aspects which were categorized as good (85.70\%). Based on these data, it can be concluded that students' attitudes towards social distancing in Senior High School are very good and positive. For differences in student attitudes, it was discovered that there was no difference in the attitudes of senior high school students towards social distancing during the Covid-19 pandemic from various variables (gender, age, class, school location) in Senior HighSchools.
\end{abstract}

Keywords: student attitudes, social distancing, covid-19

\section{INTRODUCTION}

All parts of the world, including Indonesia, are still struggling to overcome Covid-19. According to (Aufar\&Raharjo, 2020) the impact of this outbreak does not only occur in the health sector but is multidimensional. (Joharudinet al., 2020) added that this outbreak had an impact on changing people's lives. On this basis, the government has issued various handling steps to prevent the Covid-19 outbreak, such as implementing social and physical distancing (Wijaya et al., 2020). The application of social distancing as a whole can make the distribution path curve decrease (Pratama\&Hidayat, 2020). However the application of social distancing is still widely ignored by the Indonesian people (Risfianty, 2020), the community seems to underestimate and consider this outbreak as an ordinary virus and only dangerous for old people (Pratama\&Hidayat 2020). This is also evidenced by the inadequate actions and low public support for government policies (Joharudin et al., 2020).

Several studies have found that social distancing is mostly known and understood by the community, but there are still those who violate these provisions and think that social distancing will cause social relations to become distant (Pratama\&Hidayat 2020). The results of the study (Yanti et al., 2020) show that people have $99 \%$ good knowledge, $59 \%$ positive attitude, and $93 \%$ good behavior related to social distancing, people who have good knowledge show $58.8 \%$ positive attitude and good behavior $93.3 \%$, while people who have a positive attitude show good behavior 96.7\%. In line with the findings above, the results of the study (Purnamasari\&Raharyani, 2020) also show that public knowledge regarding Covid-19 is in the good category with a percentage of $90 \%$ and only $10 \%$ in the sufficient category, the habit of using masks shows good behavior as much as $95 \%$. This is in line with the findings above, the results of the study (Utami et al., 2020) show that $83 \%$ of people have good knowledge, $70.7 \%$ of people have a good attitude and $70.3 \%$ have good skills in preventing Covid-19. Furthermore, the results of the study (Widyaningrum\& Putri, 2020) show that the majority of people doing activities outside the home are $86.2 \%$ and $33.8 \%$ are still doing activities outside the house 4 or more times aday. 
Based on the results of the study above, no one has examined the students' attitudes towards social distancing Covid-19, especially at the senior high school level. In reality, this attitude is very important for a special assessment. (Riwahyudin, 2015) Attitude is a person's readiness to take certain action against a condition that is happening so that someone is ready to act. Also, there is still a lack of assessment of attitudes from various variables, namely (gender, age, class, and school location). The location of student schools in rural and urban areas will have different knowledge and actions in carrying out social distancing. Even before the pandemic, the service quality was still problematic (Sukardi et al., 2019). Students in remote villages with students in cities have different knowledge (Hariyono, 2013; Yuliawan\&Herpandika 2019) Especially in areas that are categorized as marginal with all infrastructure limitations (Sukardi et al., 2014).

Thisstudy used a quantitative approach to the survey type. The survey method involves a systematic, in-depth, and comprehensive analysis of information (Ary et al., 2010). Surveys describe quantitatively some trends, behaviors, or opinions of a population by examining a sample of that population (Creswell, 2019). The population in this study were all senior high school students in East Lombok Regency with a total of 14.655 (BPS, 2020). The number of samples in this study was 389 students, the minimum sample was taken using the Slovin formula. Furthermore, sampling was carried out by accidental sampling technique. The number of respondents who filled out the questionnaire was 624 with 194 male respondents and 430 female respondents.

The data collection technique in this study used a questionnaire, which was adapted from (Azwar, 2007), with indicators of cognitive, affective, and connotative components. All instruments use a Likert scale with 5 choices (score $1=$ strongly disagree to $5=$ strongly agree) via a google form. The results of the validity test of the instrument using the Pearson correlation coefficient product- moment (r), obtained 20 items with valid results. Then the results of the reliability test using the formula Alpha Cronbach obtained a correlation coefficient value of 0.855 with very highcriteria.

Overall data on student attitudes towards social distancing were analyzed statistically descriptive and comparative analysis. Before the test was comparative analysis carried out test requirements analysis, namely normality and homogeneity. The normality test uses the Kolmogorov-Smirnov test and the homogeneity test uses the Levene statistic. All data were analyzed using the assistance of the program SPSS version 22.00 for windows.

\section{RESEARCH RESULTS}

\subsection{Descriptive Statistics}

The results of descriptive statistical analysis of the attitudes of students in senior high school towards the social distancing of Covid-19 can be seen in the figure below.

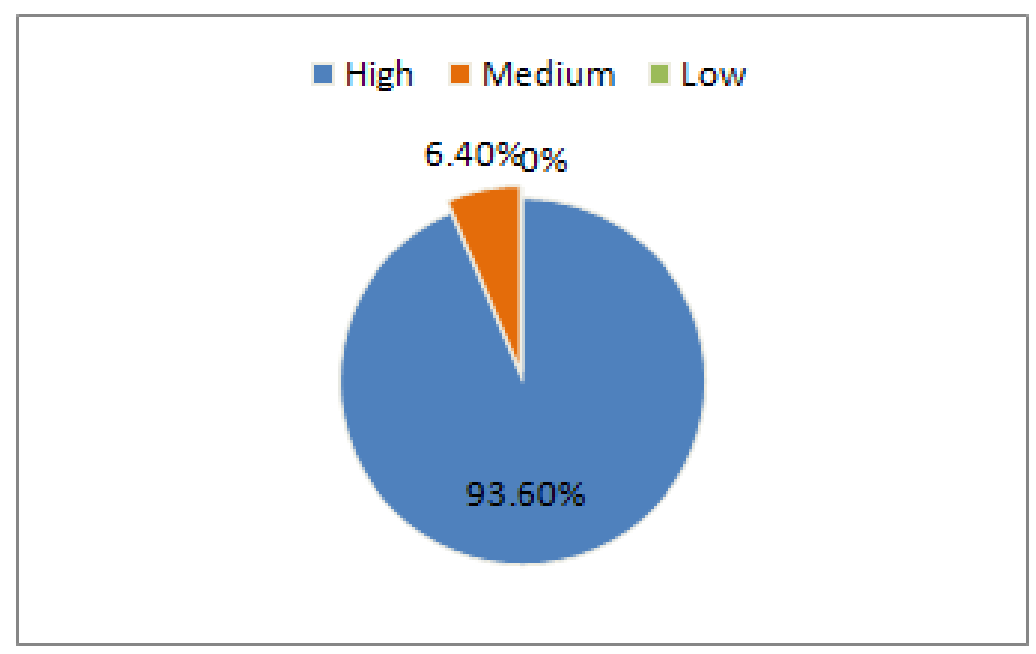

Figure 1. The cognitive components of senior high school students towards social distancing

Based on the survey results showed that out of 624 respondents who filled in the data, there was senior high school students' knowledge of social distancing in the high category with a percentage of $93.60 \%$, for the category of moderate knowledge as many as $6.40 \%$ and low knowledge of $0 \%$. Of all the respondents know and have knowledge regarding the social distancing of Covid-19. 


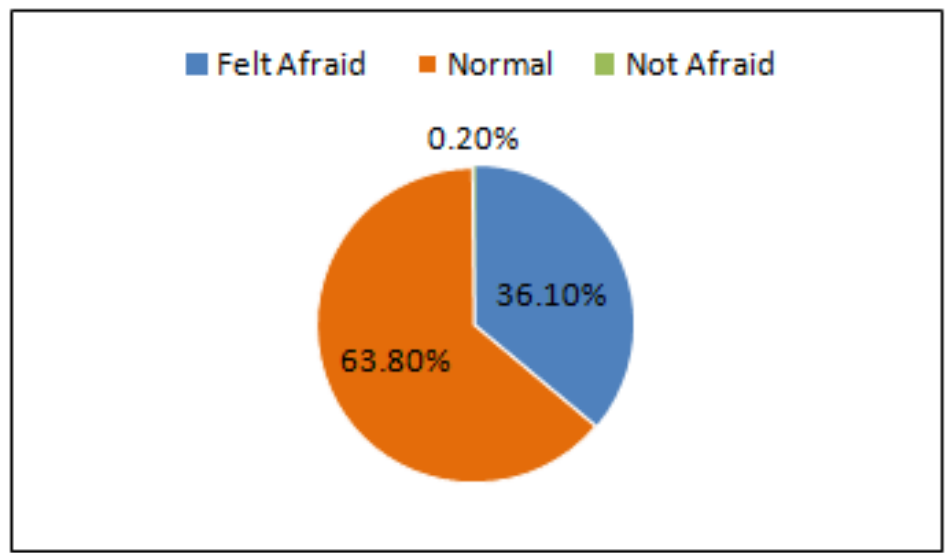

Figure2. The affective component of senior high school students towards social distancing.

Based on the survey results, it shows that of the 624 respondents who filled in the data, $36.10 \%$ stated that they felt afraid and disturbed by the implementation of social distancing63.80 Covid-19, saying that it was normal\% and are not afraid of the $0.20 \%$ percentage.

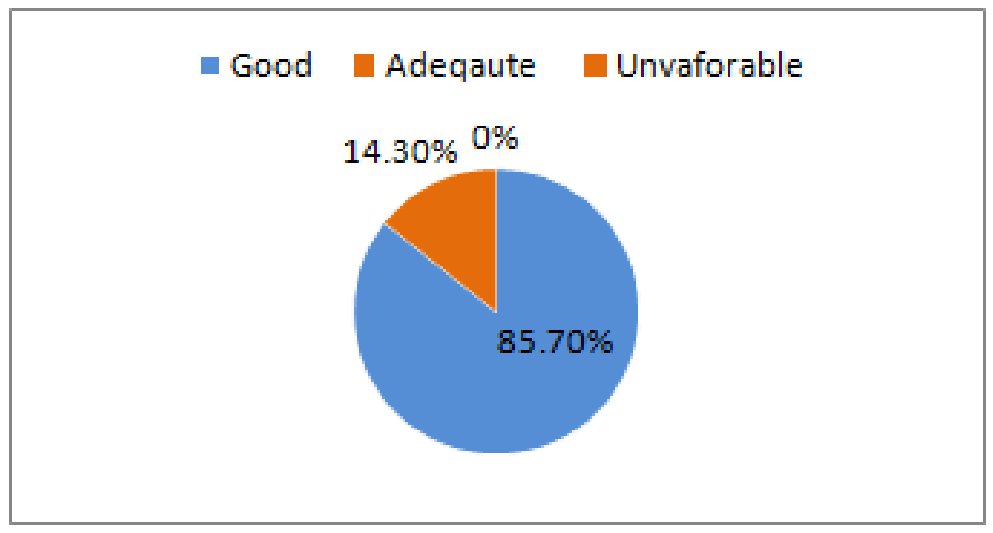

Figure 3. The connotative components of senior high school students towards social distancing

Based on the survey results show that of the 624 respondents who filled in the data, there were actions of senior high school students towards social distancing policies that were in the good category with a percentage of $85.70 \%$, for the adequate action category as much as $14.30 \%$ and $0 \%$ unfavorable action. Of all the respondents, it was found that Senior High School students obey and carry social distancing Covid-19well.

The results of the descriptive statistical analysis of the differences in attitudes of students in senior high school towards social distancing Covid-19can be seen in the table below.

Table1. Summary of Students' Attitudes from Various

\begin{tabular}{|c|c|c|c|c|c|}
\hline Variables & N & Min & Max & Mean & Std. \\
\hline Gender & & & & & 9.419 \\
\hline Male & 194 & 34 & 100 & 68.32 & 6.808 \\
\hline Female & 430 & 40 & 99 & 73.49 & 7.763 \\
\hline Age & & & & & 8.341 \\
\hline 16 years & 329 & 38 & 100 & 72.32 & 8.527 \\
\hline 17 years & 210 & 40 & 99 & 71.55 & 8.131 \\
\hline 18 years & 85 & 34 & 89 & 71.00 & 8.488 \\
\hline Class & & & & & 7.505 \\
\hline Class X & 186 & 45 & 100 & 72.82 & 8.528 \\
\hline Class XI & 224 & 34 & 99 & 71.20 & 8.234 \\
\hline Class XII & 214 & 47 & 90 & 71.78 & 6.693 \\
\hline Location of School & & & & & 71.32 \\
\hline Isolated & 222 & 40 & 100 & 91.97 & \\
\hline Outskirts town & 280 & 34 & 99 & & \\
\hline City & 122 & 52 & 89 & 72.70 & \\
\hline
\end{tabular}

Source: Primary Data Processing 


\subsection{Results of the Prerequisite Analysis}

Test The analysis requirements test in this study was carried out by testing the normality and homogeneity. The results of the normality test used the Kolmogorov-Smirnov test, while the homogeneity used the test homogeneity of variance test by looking at the value Levene statistic. The normality test is as follows.

Table2. Normality Test Results

\begin{tabular}{|l|l|l|l|}
\hline Variable & K-S Test & Sig. & Information on the \\
\hline attitudes of senior high school students & 0.080 & 0.000 & Not Normal \\
\hline
\end{tabular}

\section{Source: Primary Data Processing}

The results of the normality test show Sig. $0.000<0.05$ with these results it can be concluded that the data regarding student attitudes towards socialCovid-19 distancing in senior high school comes from data that is not normally distributed.

\subsection{Hypothesis Testing}

Testing is done by non-parametric. Hypothesis testing is done using the Mann-Whitney test and the Kruskal-Wallis test. The results of the hypothesis are as follows.

Table3. Hypothesis Test Results on Student Attitudes from Various Variables

\begin{tabular}{|c|c|c|c|c|c|c|c|}
\hline Dimensional & Category & $\mathrm{N}$ & Mean & Sd. & Mwu / Kwu & $\mathrm{p}$-value & Ket. \\
\hline \multirow[t]{2}{*}{ Gender } & Male & 194 & 68.32 & 9.419 & \multirow[t]{2}{*}{26.940} & \multirow[t]{2}{*}{0.000} & \multirow[t]{2}{*}{$\mathrm{H}_{0 \text { is }}$ rejected } \\
\hline & Female & 430 & 73.49 & 6.808 & & & \\
\hline \multirow[t]{3}{*}{ Age } & 16 & 329 & 72.32 & 7.763 & \multirow[t]{3}{*}{1.051} & \multirow[t]{3}{*}{0.591} & \multirow[t]{3}{*}{$\mathrm{H}_{0}$ accepted } \\
\hline & 17 & 210 & 71.55 & 8.341 & & & \\
\hline & 18 & 85 & 71.00 & 8.527 & & & \\
\hline \multirow[t]{3}{*}{ Class } & $\mathrm{X}$ & 186 & 72.82 & 8.131 & \multirow[t]{3}{*}{4.559} & \multirow[t]{3}{*}{0.102} & \multirow[t]{3}{*}{$\mathrm{H}_{0}$ accepted } \\
\hline & XI & 224 & 71.20 & 8.488 & & & \\
\hline & XII & 214 & 71.78 & 7.505 & & & \\
\hline \multirow[t]{3}{*}{ School layout } & City & 122 & 72.70 & 6.693 & \multirow[t]{3}{*}{2.564} & \multirow[t]{3}{*}{0.277} & \multirow[t]{3}{*}{$\mathrm{H}_{0}$ accepted } \\
\hline & P.City & 280 & 71.97 & 8.234 & & & \\
\hline & Secluded & 222 & 71.32 & 8.528 & & & \\
\hline
\end{tabular}

Source: Primary Data Processing

Based on the summary as is Table 3, it can be explained as follows.

H1: It is suspected that there are differences in students' attitudes towards social distancing Covid19in senior high school based on gender. Based on the results of the test using SPSS, the value was obtained Mann-Whitney test research -26.940 with a probability value of $0.000<0.05$. Based on these results, it can be concluded that there are differences between the genders (women and men) regarding the attitudes of senior high school students towards social distancing Covid-19. This difference is considered significant based on the probability value.

H2: It is that there is no difference in students' attitudes towards assumed social distancing Covid19in senior high school based on age. Based on the test results using SPSS, the Kruskal-Wallis test value of the study was 1.051 with a probability value of $0.591>0.05$. Based on these results, it can be concluded that there is no difference in attitudes between ages (16 years, 17 years, and 18 years) in high school towards social distancing Covid-19.

H3: It is that there is no difference in student attitudes towards the assumed social distancing of Covid-19 in senior high school by class. Based on the test results using SPSS, the Kruskal- Wallis test value of the study was 4.559 with a probability value of $0.102>0.05$. Based on these results, it can be concluded that there is no difference in attitudes between classes (X, XI, and XII) in SMA towards social distancingCovid-19.

H4: It is that there is no difference in student attitudes towards assumed social distancing Covid-19in senior high school based on the location of the school. Based on the results of the test using SPSS, the Kruskal-Wallis test value of the study was 2.564 with a probability value of $0.277>0.05$. Based on 
these results, it can be concluded that there is no difference in attitudes between the location of the school in senior high school towards social distancing Covid-19.

\section{Discussion OF STUdent ATTITUdes}

Based on the data above, it can be concluded that students' attitudes towards 'Social distancing Covid19 in SMA, the cognitive component shows good knowledge. The results of this study indirectly confirm the research (Pratama\&Hidayat, 2020) which shows that most social distancing is already known and understood by the community, as well as research conducted by (Yanti et al., 2020) shows that people have good knowledge. Related to social distancing. This is in line with research (Utami et al., 2020) showing that the community has good knowledge regarding social distancing, and (Purnamasari\&Raharyani, 2020) shows that the people of Wonosobo Regency have good category knowledge regarding Covid-19. Likewise, the results of this study indicate that students in senior high school already know and understand the purpose of social distancingCovid-19.

The results of the study of the connotative components of senior high school students towards the social distancing Covid-19policy show a good attitude. This research is supported by (Yanti et al., 2020) showing that people have good behavior in carrying out social distancing. The same thing is reinforced by research (Utami et al., 2020) showing that the community has a good attitude towards preventing Covid-19 by carrying out social distancing. Furthermore, the results of this study are in line with (Purnamasari\&Raharyani, 2020) showing that people have good behavior and behave quite well, seen from the community diligently using masks and washing hands and carrying out social distancing. This is also in line with the results of the study (Usman et al., 2020) showing that students have a good attitude in preventing Covid-19 transmission. Likewise, the results of this study indicate that students in senior high school have a good attitude in carrying out social distancing as seen from the students diligently using masks, washing their hands, and avoiding crowds. This study is different from (Sagala et al., 2020) in that the level of community compliance in carrying out social distancing is still low, residents have activities outside the house for recreational purposes, sitting in groups, gathering without wearing masks, or maintaining adistance.

Furthermore, the results of this study indicate that there are differences in attitudes between men and women on the social distancing during the pandemic Covid-19 with the percentage of female students amounted to $68.91 \%$ better than male students $31.09 \%$. The results of this study indirectly confirm the research (Novianaet al., 2020). Furthemore, the study found that there is a tendency for female students to have batter perceptions of social distancing during the pandemic, compared to male students. As for the variables of age, class, and school location, there were no differences in the attitudes of students in SMA according to the results of the analysis that had been done. It is different from the research conducted by (Hariyono, 2013; Yuliawan\&Herpandika, 2019) that students who are in remote villages with students in cities have different knowledge.

\section{CONCLUSION}

Based on the results of data analysis and discussion that has been carried out, it can be concluded that students' attitudes towards social distancing tend to be positive, as seen from the cognitive aspects of students in senior high school towards social distancing in the positive attitude category with a percentage of $98.9 \%$, affective aspects of attitudes. Positive students were $91.7 \%$ and the connotative aspects were in the positive category with a percentage of $97.3 \%$. For differences in student attitudes, it was found that there were no differences in attitudes of students in senior high schools towards social distancing during the Covid-19 pandemic from various variables (gender, age, class, school location) in Senior High Schools.

\section{ACKNOWLEDGMENTS}

The writing of this article was supported by the Sociolojgy Education Study Program, Faculty of Teacher Training and Education, University of Mataram. 


\section{REFERENCES}

[1] Ary, D., Jacobs, L. C., Sorensen, C., \&Razavieh, A. (2010). Introduction to research in education. Eighth Edition. Wadsworth, USA: CengageLearning

[2] Aufar, A. F., \&Raharjo, S. T. (2020). Kegiatanrelaksasisebagai coping stress di masa pandemi COVID19. JurnalKolaborasiResolusiKonflik, 2(2), 157-163.https://doi.org/10.24198/jkrk.v2i2.29126

[3] Azwar, S. (2007). Sikapmanusia: Teori dan pengukurannya. Yogyakarta: Pustaka Pelajar.

[4] Badan Pusat Statitistik/BPS Lombok Timur. (2020). Kabupaten Lombok Timur dalam Angka 2020. Selong: BPS Lombok Timur

[5] Creswell, J.W. (2019). Risetpendidikanperencanaan, pelaksanaa, dan evaluasirisetkualitatif \&kuantitatif (Edisi ke-4). Yogyakarta: Pustaka Pelajar.

[6] Hariyono, R. (2013). Perb and inganting katke bugaranjasmanisiswakelas X berdasar kanletakgeografis (Studi pada siswaputera Kelas X SMA Negeri 1 Ngadirojodan SiswaPutera Kelas X SMA Negeri 1 Tulakan). Jurnal Pendidikan Olahraga dan Kesehatan, 1(2).

[7] Joharudin, A., Septiadi, M. A., Maharani, S., Aisi, T. D., \&Nurwahyuningsih, N. (2020). Panic syndrom Covid-19: Penekananterhadapkebijakan yang diberikan. JurnalPerspektif, 4(1), 4453.http://dx.doi.org/10.15575/jp.v4i1.63

[8] Noviana, M., Sukardi, S., \& Suryanti, N. M. N. (2020). Learningprocessduring covid-19 pandemicfromvariousvariables in Senior HighSchool.ScienceandResearchJournal, 3 (4), 160-165. https://doi.org/10.18421/SAR34-03.

[9] Pratama, N. A., \&Hidayat, D. (2020). Pengetahuan dan perilakumasyarakatmemaknai social distancing. Journal Digital Media \& Relationship, 2(1)

[10] Purnamasari, I., \& Raharyani, A. E. (2020). Tingkat pengetahuan dan perilakumasyarakat Kabupaten Wonosobotentang Covid-19. Jurnalllmiah Kesehatan, 10(1), 33-42.

[11] Risfianty, D. K., \&Fitriah, L. (2020). Masker gratis dan informasi social distancing bagimasyarakat Dusun Motong Are Tengah. INTAN CENDEKIA: JurnalPengabdian Masyarakat, $1(1), \quad 1$ 8.https://doi.org/10.47165/intancendekia.v1i1.54.

[12] Riwahyudin, A. (2015). Pengaruhsikapsiswa dan minatbelajarsiswaterhadaphasilbelajar IPA Siswa Kelas V Sekolah Dasar di KabupatenLamandau. Jurnalpendidikandasar, 6(1), 1123. https://doi.org/10.21009/JPD.061.02.

[13] Sagala, S. H., Maifita, Y., \&Armaita, A. (2020). Hubunganpengetahuan dan sikapmasy arakatterhadap Covid-19: A literature review. Menara Medika, 3(1). https://doi.org/10.3 1869/mm.v3i1.2197.

[14] Sukardi, S., Ismail, M., \&Suryanti, N. M. N. (2014). Model pendidikankewirausahaanberba sisketerampilanlokalbagianakputussekolah pada masyarakat marginal. Cakrawala Pendidikan, (3), 84826.https://doi.org/10.21831/cp.v3i3.2384

[15] Sukardi, S., Rusdiawan, R., \&Wardana, L. (2019). The competitiveness of master of education graduates: Porter's Diamond analysis. International Journal of Emerging Tehcnologies in Learning (iJET), 14(19), 179-187.

[16] Usman, U., Budi, S., \& Sari, D. N. A. (2020). Pengetahuan dan sikapmahasiswakesehatantent angpencegahan covid-19 di Indonesia. JurnalImu Keperawatan dan Kebidanan, 11(2), 258264.http://dx.doi.org/10.26751/jikk.v11i2.835.

[17] Utami, R. A., Mose, R. E., \& Martini, M. (2020). Pengetahuan, sikap dan keterampilanmasyarakatdalampencegahan COVID-19 di DKI Jakarta. Jurnal Kesehatan Holistic, 4(2), 6877.https://doi.org/10.33377/jkh.v4i2.85.

[18] Widyaningrum, N., \& Putri, Y. D. (2020). Gambaran penerapan physical distancing sebagaiupayamenekanpersebaranCovid-19 di Provinsi Daerah Istimewa Yogyakarta. Nusantara: JurnallmuPengetahuanSosial, 7(2), 470-481.http://dx.doi.org/10.31604/jips.v7i2.2020.470-481.

[19] Wijaya, R., Lukman, M., \&Yadewani, D. (2020). Dampakpandemi Covid19 terhadappemanfaatan elearning. JurnalDimensi, 9(2), 307-322.

[20] Yanti, B., Wahyudi, E., Wahiduddin, W., Novika, R. G. H., Arina, Y. M. D. A., Martani, N. S., \&Nawan, N. (2020). Community knowledge, attitudes, and behavior towards social distancing policy as prevention transmission of Covid-19 in Indonesia. JurnalAdministrasi Kesehatan Indonesia, 8(2), 4-14. https://doi.org/10.3390/ijerph17176256. 
[21] Yuliawan, D., \&Herpandika, R. P. (2019, October). Studikondisifisikditinjauberdasarkan strata pendidikan dan letakgeografis di Kota Kediri. In Prosiding Seminar Nasional IPTEK Olahraga (SENALOG),2(1).

Citation: Wahyu Fitrianil, Sukardi2*, Hairil Wadi. " Student Attitudes Toward Social Distancing During the Covid-19 Pandemic in Senior High School" International Journal of Humanities Social Sciences and Education (IJHSSE), vol 8, no. 2, 2021, pp. 197-203. doi: https://doi.org/10.20431/2349-0381.0802020.

Copyright: () 2021 Authors. This is an open-access article distributed under the terms of the Creative Commons Attribution License, which permits unrestricted use, distribution, and reproduction in any medium, provided the original author and source are credited. 